https://doi.org/10.22364/hssl.28.2.07

\title{
INFORMATION AND COMMUNICATION TECHNOLOGY (ICT) UTILIZATION: A VERITABLE TOOL FOR ACADEMIC STAFF EFFECTIVENESS IN NIGERIAN POLYTECHNICS
}

\author{
Abdulrahaman Olanrewaju Ibrahim \\ $\mathrm{PhD}$
}

\author{
Alabi Afusat Titilayo \\ $\mathrm{PhD}$ \\ Yusuf Suleiman \\ B.Ed., M.Ed. \\ Mustapha Adam Ishola \\ MA
}

\begin{abstract}
There is no doubt about the fact that information and communication technology utilisation (ICT) is a life wire of any school organisation. However, planners and administrators are aware of the contributions that ICT utilisation could make to the enhancement of academic activities of the institutions. The attainment of the goals and objectives of higher institutions of learning required the availability and optimal utilisation of ICT. Based on the foregoing premise, this study examined ICT utilisation as a veritable tool for academic staff effectiveness in Nigerian Polytechnics. The concept and importance of ICT utilisation were critically examined. Challenges associated with ICT utilisation were highlighted, which include unsteady power supply, inadequate funding, poor quality of telecommunication connections, and lack of qualified ICT operators. The study concluded that the contribution of ICT utilisation to the development of entire level of education today make it necessary for the adoption of ICT utilisation by the school authorities, administrators as well as the lecturers in such a way that it easier for the utilisation of application packages (like power point presentation, Microsoft word process, spread sheet and so on), internet application (video conferencing, e-mail, data base, e-learning) and computer hardware facilities (photo copier machine, printing machine, scanners, laptops to mention but a few). This helps to improve the quality of teaching-learning process, academic and administrative effectiveness in institutions. Also, the technological devices of an institution are a major determinant factor in the actualisation of its objectives. The study recommends that proper funding should be provided for the procurement of ICT devices and equipment which are capital intensive.
\end{abstract}

Keywords: Nigeria, ICT, Utilization, Effectiveness, Polytechnics 


\section{Introduction}

The emergence of information and communication technology (ICT) has brought a pertinent turnaround to educational development worldwide particularly in Nigerian Polytechnics. In terms of making lecturers more relevant in the world of work and also facilitates teachinglearning processes. In higher institutions of learning, especially Nigerian Polytechnics, academic staff play a significant roles in the achievement of polytechnic's goals as stated in National policy on Education (2014) which include teaching, research, dissemination of existing and new information, pursuit of services to the community and being a store house of knowledge. For the attainment of these responsibilities effectively necessitate the use of ICT (National Policy on Education, 2014). For this reason, there is need for ICT utilisation in terms of power point presentation, e-learning and laptop/computer and so on, which are useful to the effectiveness of academic staff of Polytechnics. The truth remains that, ICT utilisation holds the promise of improved effectiveness (Akuegwu, Ntukidem \& Jega, 2011; Mitomo, 2020; Victor \& Faga, 2015).

Despite the importance of ICT utilisation in ensuring academic staff effectiveness in the global world it appears that some lecturers in African higher institutions particularly Nigerian Polytechnics are not effective as expected due to inability to adopt ICT utilisation to their daily responsibilities in terms of teaching, research and publications. as well as community services in their various institutions (Dalhatu, Mamman \& Abdullah, 2020). To justify this fact, Victor and Faga (2015) asserted that the promise that ICT utilisation holds is not actualised due to the limitless abilities of lecturers to make use of it. Guardian (2007) corroborated that the application of ICT to teaching- learning and research publications in Nigerian tertiary institutions is less than five percent. Also, some lecturers are not effective because of limitless ability to make use of ICT. Some lecturers in higher institutions are yet to acquire the requisite ICT skills, even when opportunities exist.

The reform process involved an effective integration of ICT into various curricula with the intention of providing learners with knowledge of basic and applied an aspect of ICT that can make learning appreciable and accessible while at the same time enhancing professional productivity (Gyaase, Gyamfi, Kuranchie \& Koomson, 2020; Tomei, 2005). Oniye, Yahaya and Alawaye (2011) opined that the integration of information and communication technology into teaching-learning process in higher institutions of learning would make learning more efficient and productive thereby engendering a variety of tools to enhance and facilitate lecturers' pedagogical activities and students 'academic performance. Nwankwo (2014) pointed out that no matter how good the curricula content is if 
the methods and conditions for classroom instruction are insufficient, the teaching-learning process will fail. Furthermore, the modern information explosion and the impact of access and popularisation of ICT among the youth, make it important for today's teachers to be encouraged to concentrate more on teaching students how to learn than what to learn. However, the lecturer's role in the school no doubt contributes in determining the success of any educational system.

It is, therefore, imperative to ascertain how lecturers can also benefit from the use of information and communication technology (ICT) in carrying out their daily activities. Hence, information and communication technology has impacted on the quality and quantity of teaching, learning and research in traditional and distance institutions. ICT also enhances through teaching and learning through its dynamic alternative and engaging content, it strengthens teaching and provides opportunities for connections between the schools and the world and it makes the school more efficient and productive, thereby engendering a variety of tools to enhance and facilitate teacher's professional activities. Hence, the institution's top managers, that is, the reactors must be interested in the adoption of information and communication technology utilisation since they play key roles in its implementation. The school managers ensure a match between information and communication technology utilisation and academic staff effectiveness within the institutions in terms of students' learning outcome.

Academic staff effectiveness is very crucial to any organisation because it may be one of strongest pillar of a higher institution of learning. Where positive results (quality output) expected from lecturers of polytechnics through teaching-learning, staff research performance, community services as well as students' academic performance so as to achieve the stated goals and objectives of polytechnic education (Adediwura \& Tayo, 2007, Adu \& Olatundu, 2007; Babatunde and Victor, 2014). In a similar view, Adeyemi and Uko-Aviomah (2003) articulated that teaching staff is the mainstay of any institution and their number and quality affect the teaching-learning process. Lecturers are however the significant input in the transformation of students into graduates and providers of the knowledge and solutions to the societal problems. Ali (2006) postulated that academic staff is experienced and frontline scholars in their diverse disciplines and those who may utilise the required vital teaching and learning facilities as well as opportunities for professional and career growth in such system. Academic effectiveness is the result of education, the extent to which a student and lecturer or institution have achieved their educational goals. The effect of lecturers or teachers' teaching effectiveness on the learning outcome of students as judged by students' academic performance has been the subject of several studies 


\section{Concept of information and communication technology}

ICT is an extensional term for information technology (IT) that emphasises the unique role of unified communications in the integration of telecommunications (wireless signals and telephone lines) and supercomputers, as well as necessary software, middleware, storage and audio-visual systems, which enable users to have access, store, transmit, and operate information. ICT can also be described as the convergence of telephone and audio-visual networks with computer networks via a single link system or single cabling (Goh \& Sigala, 2020; Habibi, Yusop \& Razak, 2020). Though, there are great economic incentives to combine the telephone network with the laptop network system using a single united system of signal distribution, cabling and management. Thus, ICT is a canopy term that includes any communication device, television, encompassing radio, cell phones, network hardware and computer, satellite systems and so on, as well as the numerous services and applications with them such as distance learning and video conferencing. More so, ICT is seen as a broad subject and the thoughts are evolving. ICT covers any product that will retrieve, manipulate, transmit, or receive information electronically via digital form, (e.g., digital television, email, robots, personal computer, personal computers). The theoretical differences between interpersonalcommunication technologies and communication technologies have been identified by the Piyush Mathur. Skills Framework for the Information Age is one of many replicas for managing and describing competencies for ICT teachers for the 21st century (Ifinedo, Rikala \& Hämäläinen, 2020; Suárez-Rodríguez, Almerich, Orellana \& Díaz-García, 2018).

The origin of information and communication technology (ICT) as a tool for work efficiency can be linked with the innovation of the abacus which is a counting device about 3000 B.C. The development of the abacus meant specifically for carrying out minimal calculation both in business and nonbusiness ventures. The development of information and communication technology (ICT) in its modern form can, therefore, be traced back to the 16th century (Greene, 2013). Mohammed and Yarinchi (2013) postulated that the inception, growth and impact of information technology can be traced to the origin and impact of industrial revolution. It was during the era of industrial turnaround that effort was made to inculcate the use of technology in the production process. This achievement was gradually transferred to other countries around the world including Nigeria. Also, the development of information and communication technology (ICT) and its application to education and training has increasingly permitted institutions to utilise and deliver learning in various ways.

Presently, the choice of venue is driven by among other things' the ability to access the learning materials using ICT. These technologies 
have made walls of the learning space transparent", providing a freedom for the learners to explore sources of information within and outside their institutions, even outside their country (Abdulhamid, Ahmed \& Babawuro, 2007; (Adewoyin \& Fawole, 2008). Aliogo (2005) perceived that people are in a revolutionary global knowledge; however, people need to be conscious of what they claim to know today, which may become obsolete tomorrow. Education is what people know today, however, people need to be conscious of time and dynamics within the time frame.

Information according to Iheanacho (2004), it can be described as the basic driving force behind any useful assistance a counsellor, manager or a psychologist offers to his client. Information technology is also the study or use of electronic equipment particularly, computer for storing, analysing and sending out information. It is also referred to the processing of collating, storing and sending out useful information. Oniye, Yahaya and Alawaye (2011) opined that information and communication technology as the method and technical means of capturing, storing, processing, retrieving and transmitting data (and knowledge) through multimedia electronic-based approach. Onwumere (2008) perceived information and communication technology as a collective term used to indicate the collection of electronic machines(both hardware and software) that make them work in the collection, storage, processing and transmission, retrieval, presentation and communication of information particularly students in institutions of higher learning. These technologies comprised computers, the internet, broadcasting technologies (radio and television) among others. It provides immediate feedback to students to enable them to monitor their progress. Information and communication technology are as pertinent as the air people breathe. Indeed, it is the major evolution of the time.

As it is observed, the bedrock of any information communication technology is the computer, thus without the knowledge of computer, one is but a living dead. Freeman and Hasnaoui (2010) suggested that information and communication technology is used to refer to an electronic-based system of information transmission, reception, processing and retrieval, which has drastically changed the way people think, the way people live and the environment in which people live. This indicates the fact that ICT facilities and equipment are devices which make the accumulation and dissemination of information easier and faster across borders. Information and communication technology (ICT) are a combination of technological devices that are developed for the purpose of sharing information and communication. Ogunlade (2008) opined that ICT could be regarded as a tool for teachers but not to be substituted for the teachers. In a related development, ICT has the potential of being 
used to meet the learning needs of an individual student, promote equal educational opportunities, offer high-quality learning materials, increase self-efficiency and independence of learning among students and improve students' development.

\section{ICT utilisation in Nigerian polytechnics}

Yusuf (2005) defined ICT utilisation as the presentation and distribution of instructional content through web environment (e-learning) to support learning and communication. Ntui and Inyang (2015) expressed that ICT utilisation to large extent determine academic staff effectiveness if it properly implemented. Aduwa-Ogiegbaen and lyamu (2005) accepted that, proper ICT utilisation holds enormous promise to improve teaching and learning in addition determining workforce opportunities. The use of ICT in teacher professional development entails two sets of activities or roles: The first one is training teachers to learn about ICT and its use in teaching as computers introduced to schools, the second role is to provide for teacher education, whether as a core or principal component of a programme or enabling role within it.

ICT utilisation as regards the learning process can be subdivided into three various parts: as an object, aspect, or medium. As an object, it relates to learning about ICTs as specific courses such as computer education. Learners acquainted themselves with hardware and software, including packages such as Microsoft Word, Microsoft Excel, and others. The main purpose is computer literacy. As an aspect, it refers to application of ICTs in education related to what obtains in industry. ICT in education, such as computer- aided design and computer-aided instruction, are examples used to support teaching and learning. Thus, ICT utilisation enables lecturers to work together and communicate with other lecturers all over the world and this enhances their work performance (Akpan, 2014; Oluwafemi, 2011).

\section{Importance of ICT in Nigerian polytechnics}

According to United Nations Educational, Scientific and Cultural Organisation (UNESCO), which is an organ of the United Nations (UN), has ensured the integration of ICT into education sector as part of its determinations to ensure access and equity to education system across the globe. Deducing from the UNESCO's book on educational ICT, which explains the establishment's position on the initiative, it explains that ICT has the capacity that can be used to contribute to universal access to education, delivery of quality teaching and learning, equity in education, development of teachers' professionalism and more efficient management 
of education, administration, and governance. The UNESCO takes a comprehensive and holistic approach to promote Information and Communication Technology in all facets of education. Also, access, inclusion as well as quality are the prominent main challenges they can address. In the same vein, the organization's intersectoral podium for ICT in education centres on these matters through the joint work of three of its sectors: Communication \& Information, Science and Education (Rana, Greenwood \& Fox-Turnbull, 2020).

The fast expansion in ICT has brought outstanding transformations in the $21^{\text {st }}$ century and positively influenced the demands of modern world (Bandele, 2008). According to Ifinedo (2006), tertiary institutions all over the world have been integrating information and communication technology for teaching and learning technologies in an attempt to create an enable environment for both teachers and students of engaging in combined learning and gain access to information. Givang (2009) suggested five components of ICT tools for innovation in school. It is viewed as subject (i.e. computer studies), a tool of innovation in teaching and learning process (i.e. digital content, multimedia, teaching-learning methods, learning context), ICT as an administrative management tool (i.e. Educational Management Information System - EMIS), expansion of learning opportunity (i.e. distance learning and e-learning) and ICT as a facilitation of higher-order thinking skills (i.e. learner-centred selfdirected learning, tailored learning).

Nwaoka and Okoli (2012) suggested that any resource personal that is lacking in ICT would be boring repetitive and would produce very little. However, Egbebi (2014) articulated the following relevance of ICT: Use of electronics computer software to convert, store, protect, process, transmit and retrieval information, message transmission is no longer a tedious process, but it speed up consideration for the exigencies of time and space, utilising computerised system to carry out many activities and also to achieve their institutional goals, some of the activities and entail, conducting research, conducting examination for students (e-exam) course registration, online-application for prospective student, student hall allocation, school fee payments, typing of question papers, keeping of student records, keeping of staff records, results typing and processing, sending and retrieving information to other institution to mentioned but few.

\section{Concept of academic staff effectiveness}

Academic departments are the core of the tertiary educational institutions. It is at these units that business of educating students and research aimed at moving the society forward gets conducted. If 
the academic department is that essential in attaining higher educational objectives, the departmental development must be a product of strategic planning. However, given the important role of the Head of Department, one would expect that their performance will be periodically evaluated to ensure effectiveness in the management of the academic department (Archibong, 2006). Higher educational institutions are expected to pursuit their goals through teaching, research, dissemination of existing and new information, and pursuit of service to the community and should be a storehouse of knowledge (National Policy on Education, 2014). Popoola (2008) regarded academic staff as lecturers in the academic organisations whose responsibilities concern to teaching, learning, research and community services. This means that lecturers of Nigerian Polytechnics are expected to carry out their day to day activities diligently in terms of facilitating teaching and learning, publishing journals and offering public lectures for community services in order to ensure their effectiveness.

Teaching is a process of grooming an individual to become successful in life. It is also can be regarded as way of imparting knowledge to learners. According to Acharu (2015), teaching is dynamic process in which lecturer shares information with learners in order to provide them with the information needed for behaviour changes. According to Ogunsaju (2004), effectiveness involves the interdependent relationships among purpose, effort and accomplishment. It is the desire of every teacher to be effective. Effective teaching is the process of identifying what actually works as indicated by outcomes. Basically, it is whatever a teacher does to keep his students on task. Sawhney and Kaur (2011) described teaching effectiveness as excellence or the most favourable level of efficiency and productivity on the part of the lecturers. Effective teacher is seemed to be effective with students of all academic levels of diversity in their classroom. Effectiveness in school management is justified by how well objectives of education are realised and not by some real or imagined standards for the proper management of schools. As goals change or new innovation emerges, it becomes imperative to re-examine the existing system of management.

Akuegbu, Ntukiden, Ntulgiden and Jaga (2011) described effective school as one which strives towards attaining quality learning. Research is one of the crucial points in which higher institutions of learning rests. Others include teaching and community service. Research entails of issue. It consists a key criteria for the promotion of academic staff and, as such it highly regarded, sought after acquires high level participation and quality work. The area of specialisation of academic staff determines their research productivity. Publication means the quality and quantity of research produced by academic staff. This is the justification in the number 
of published researches in local and international journals, awards obtained by staff among others. Lecturers at the same time pursuit service to the community in terms of delivery of public lectures, involvement in monitory and marking of WAEC and NECO exams, participation in training, enlightenment/re-orientation programs and so on.

\section{ICT utilisation and academic staff effectiveness in Nigerian polytechnics}

ICT utilisation is seen as veritable tools for achieving academic staff effectiveness in higher institutions all over the world particularly in Nigerian Polytechnics. The tools for the achievement of academic staff effectiveness is the utilisation of application packages (like use of power point presentation, Microsoft word process, spread sheet and so on),internet application (video conferencing, e-mail, data base, e-learning) and computer hard ware infrastructures (photo copier machine, printing machine, scanners, laptops and so on). Atsumbe, Raymond and Enoch (2012) corroborated that ICT has turned out to be veritable tools in educational methodology and curriculum delivery globally. This is in recognition of the fact that Akuegwu, Ntukidem and Jaga (2011) said that ICT utilisation refers to the utilisation of computer, lap tops, video machines, multimedia projectors or power points, digital cameras, internet facilities, computer network, telephone Global System Mobile (G.S.M) and land phones, E-library, television programmes, data base among others in the educational setting.

ICT utilisation enables lecturers to work together and communicate with other lecturers all over the world and this enhances their work performance (Akpan, 2014). The ICTs have the potentials of not only ensuring effectiveness and efficiency in the teaching and research but also have potentials of ensuring the administrative duties (Onasanya, Shehu, Oduwaye \& Shehu, 2010). Aduwa-Ogiegbaen and lyamu (2005) accepted that, proper ICT utilisation holds enormous promise to improve teaching and learning in addition determining workforce opportunities. Abdulhamid, Deba \& Babawura (2007) viewed that acquiring technologies are the apparatus for effective, high performance workers in the $21^{\text {st }}$ century. ICTs have potential to enhance the publication of educational journals in the institutions (Abdulkarin \& Ebiferi, 2007).

Larsen and Lancrin (2005) revealed that ICT is indispensable of improving the quality of tertiary education and effectiveness of teaching and learning. Ntui and Inyang (2015) expressed that ICT utilisation to large extent determine academic staff effectiveness if it properly implemented. Kumar and Kaur (2005) opined that the extensive use of internet network 
permits lecturers and researchers to successfully carryout their academic and social services. The enhancement of academic activities in Nigerian higher institutions can be assured through the use of internet and web technology that serves as a driven force for ICT utilisation. Internet surfaced as educational tool for a good source of getting the right information and solution to problems in an academic setting

Internet utilisation enables lecturers to work together and communicate with other lecturers all over the world and this enhances their work performance. Internet allows lecturers to publish educational journals in the institutions (Abdulkarin \& Ebiferi, 2007; Fasae \& Aladeniyi, 2010; Joseph, Fasa, Samuel \& Samuel, 2014). Kumar and Kaur (2005) viewed that the advent of internet has increased the following phenomena in higher educational systems: Learner is not dependent on teacher for interaction; Teachers can give lectures virtually to unknown learners and the effect of his work has no bound. Academic staff faculties use the internet in difference ways for educational purposes, such as web-based education, smart classroom application and opportunity to participate academically in cooperative learning, which actually is the major focus of internet facility that is currently in vogue. Individual learner can learn at the same pace globally. They noted that lecturers, research scholars use the internet for the purpose of teaching activities, research and study. Similarly, a study conducted by Ogunrewo and Odusina (2010) revealed that ease of downloading of related information/materials for teaching and research was given the highest priority as the reason for surfing the internet with an index of $3.88 \%$ by the academic staff members.

Igbineweka and Mani (2013) opined that based on the figures provided by National Science Foundation Network (NSFnet) as at January 2010, the internet linked more than 4.85 million computers with over 36 million users in 85 countries including Nigeria. Since then, especially in the recent past, new users have been hooking up at every 1.6 seconds (Andreas, 2012). In the emerging global world therefore, connecting the school to the internet has a number of benefits for education provision and delivery. For example, internet availability has helped many teachers to interact with their peers in other parts of the emerging global village. With this, teachers have been able to ask for help and share personal classroom experiences, a situation that has positively impacted on the teaching-learning process. According to Hepp, Hinostroza, Laval and Rehbein (2011), the importance of making the internet available to facilitate teaching and research activities in school cannot be over-emphasised. E-mail permits learners to log onto internet network at their convenience to access lectures, read assignments, and deliver completed homework or to interact with lecturers and fellow students. 
Adeyemi and Marry (2013) opined that power point presentation is being utilised by lecturers to prepare and reproduce hand-outs or make presentation of learning materials as slides in lecture rooms. The use of power point and overhead projectors for teaching and learning has significant relationship with academic staff effectiveness (Abdulhamid et al., 2007; Safahie \& Asemi, 2008; Ntui et al., 2015; Victor et al., 2015). Umoren (2006) found out that use of power point, instructional delivery is impactful to slow and fast learners. This means that power point presentation utilisation improves academic staff effectiveness. PowerPoint slide presentations used in lectures can provide a structure for the students to follow and in that sense assist with cognition. Lecturers can print out hand-outs pages and write notes next each slide as the lecture progresses. PowerPoint slide also stimulate interest and deepen understanding of a concept of students. Centre for Teaching and Learning (2014) opined that appropriate use of PowerPoint can enhance the teaching and learning experience for both staff and students. It enumerated seven benefits of using power point allows students more control of their own learning, allows lecturers to guide more, teach less, allows student to build up knowledge, and become part of the teaching process, can provide some really engaging learning experiences, teachers can provide "scaffolding" and safety nets, at risk" students can be identified more quickly.

\section{Challenges of ICT utilization}

In spite of the power of computers to reform and enhance teaching and learning processes, the improper implementation of the policy is a widespread issue which is beyond the reach of increased technological advances and funding with little proof that educators and tutors are appropriately integrating ICT into everyday learning. However, intrinsic barriers such as a belief in more traditional teaching practices and individual attitudes towards computers in education, as well as the educators' own comfort with the use of computers and their ability to use them all as result in varying effectiveness in the integration of ICT in the classroom. Also, there is some empirical evidence that, for one to be effective in education, ICT must be fully channelled into the school pedagogy. Precisely, when teaching literacy and math, using ICT in combination with writing to learn, it produces better results than traditional methods alone or ICT alone (Goh \& Sigala, 2020; Rana, Greenwood \& Fox-Turnbull, 2020).

It is a basic fact that, ICT has the ability to ameliorate the educational organisation to a great extent; some countries are far from reaping these benefits because of certain impediment. An impediment is something that slows or blocks progress (Vocabulary.Com Dictionary, 2016). It may be described as difficulties of frustration experienced in the application of ICT in Nigerian Polytechnics. These impediments among others contain: 


\section{Antiquated and poorly managed transmitting facilities}

The problem of poor and out-dated transmitting facilities is one of the problems of higher learning in Nigeria. It was obvious that most of the transmitting facilities in Nigeria are too out-dated and do not reflect the state of the art in transmitting. The equipment is, consequently, old and cannot support efficient educational broadcasting. This situation is worsened by ill-maintenance due to lack of space parts. There is, hence, poor signal reception and breakdown in communication from the station (Onwumere, 2008).

\section{Unsteady power supply}

The current status of the Power Holding Company of Nigeria Plc (PHCN) is nothing to write home about. Most of the tools for ICT, because of their encoding property need electricity as the source of power. Granting that there has been some improvement in power supply by the PHCN, the road to regular power supply is still a long one. Failure when a whole class is being instructed through ICT or Computer Based Test (CBT) or while any instructional mode is going on could be very disorganising. The irony of it all is that when PHCN strikes, it might take them more than thirty minutes or an hour to restore power.

\section{Utilisation attitude}

Most applications of the ICT tools in some Nigerian higher institutions of learning where applicable are more or less sporadic. This does not give room for real educational development. Again, the posture of various managements in and outside the institutions towards the introduction of ICT related facilities such as the internet and procurement of computer is rather poor and there may not be aided or supported by government at all (Suleman, 2008). Over utilisation of ICT means the excessive use of available electronic device in the schools. Yusuf (2005) observed ICT utilisation as the presentation and distribution of instructional content through web environment (e-learning) to support learning and communication. Akuegwu, Ntukidem and Jaga (2011) as cited in Egomo Enyi Tah. Computer lap tops, video machines, multimedia projectors or power points, digital cameras, internet facilities, computer network, telephone (G.S.M) and land phones, E-library, television programmes, data base among others.

\section{Lack of qualified ICT operators}

Findings have indicated that some lecturers are computer semi-illiterate if not outright illiterate just as some of the students. Higher institutions lack computer/ICT specialist that would support and manage the internet connection and/or application of computer on the teaching/learning process. 


\section{Inadequate funding}

This is the bane of any educational development. Without adequate funding, curriculum innovation will prove abortive or remain a mere mirage (Okojie, 2007).

\section{Poor quality of telecommunication connections}

Another problem militating against the integrating of ICT into institutions of higher learning is the issue of poor quality of telecommunication. Nigeria is one of the countries of the world that is yet to develop its telecommunication facilities to a standard that is judged excellent and this has not enabled lecturers and students that have the motivation to utilise this facility, to derive maximum satisfaction from its usage. Therefore, in few centres where good facilities are available, the service would definitely be effective. Invariably, these challenges hamper the adequate utilization of the gadgets.

\section{Conclusion}

Although the primary purpose of ICT utilisation is the improvement and sustenance of a good educational programme, the stock of ICT facilities in the polytechnic education in Nigeria and in the South-west Nigerian Polytechnics, in particular, is enormous even at the current state of their insufficiency and gross inadequacy. They represent substantial financial outlay to the providers. Whereas ICT utilisation gives meaning to the teaching-learning process, their provision and utilisation have not been adequately accorded the attention it deserved especially in South-West Nigerian Polytechnics. There is no doubt about the fact that ICT utilisation in no small measure has contributed immensely to the improvement and effective teaching and learning in the present era of globalisation. Hence, ICT utilisation in the institutions vehemently enhances the acquisition of knowledge and offers lecturers unprecedented opportunities to optimise their academic pursuit and effectiveness in more ways than one.

Both school administrators, lecturers and students have a lot of areas demanding improvement, however, there is the need for effective ICT utilisation in order to ensure academic staff effectiveness. The achievement of the goals and objectives of polytechnics required the optimal utilisation of ICT. Perhaps, if ICT is properly utilised in the institutions in terms of application packages (like power point presentation, Microsoft word process, spread sheet and so on), internet application (video conferencing, e-mail, data base, e-learning) and computer hard ware facilities (photo copier machine, printing machine, scanners, laptops to mention but few). This will make both the school managers and lecturers to be more proactive 
in their day-to-day activities. Thereby, there is tendency of attainment of academic staff effectiveness which at the same time will bring about the students' academic performance in South West Nigerian Polytechnics.

\section{Recommendations}

Based on the foregoing discussions, the following suggestions were made:

1. The government should ensure adequate provision of funding for the provision of ICT facilities and equipment for lecturers in the institutions which is usually capital intensive and requires adequate budgetary allocation.

2. Concerted efforts should be made by the government to ensure that every lecturer has access to ICT facilities for utilisation purposes.

3. Prospective lecturers should be trained in the art of management to equip them with the prerequisite knowledge of ICT utilisation strategies that would be useful when appointed as rectors or similar positions.

4. School management should organise seminars and workshops on ICT utilisation strategies so that school managers could gain in-depth knowledge and understanding in this important area of ICT utilisation.

5. Philanthropist, alumni association and well-meaning individuals in the different communities in South-West Nigerian polytechnics should assist in the provision and management of essential ICT facilities.

6. The government should ensure that contractors handling the provision of school ICT facilities that are of good and top quality. This is the first step towards any maintenance effort that will promote academic staff effectiveness in the institution.

\section{REFERENCES}

1. Abdulhamid, A., Ahmed, A. \& Babawuro, S. (2007a). Information and communication technology (ICT) and its implications on higher education in Nigeria. In A. A. Fajonyomi \& I. A. Njodi (Eds). Reforms in higher education in Nigeria. Maiduguri: Awemark.

2. Abdulhamid, A., Ahmed, A. \& Babawuro, S. (2007b). Communication technologies: A new paradigm in the effective delivery of distance learning and its implications for higher education in Nigeria. In A. A. Fajonyomi \& I. A. Njodi (Eds). Reforms in higher education in Nigeria. Maiduguri: Awemark.

3. Abdulhamid, A., Deba, A. A., \& Babawura, S. (2007). Problems and prospects of learning technologies. In A. A. Fajonyomi \& I. A. Njodi (Eds). Reforms in higher education in Nigeria. Maiduguri: Awemark.

4. Abdulkarim, I. \& Ebiferi, O. R. (2007).The role of ICT in enhancing educational journal publications among lecturers in institutions of higher learning in Nigeria. 
In A. A. Fajonyomi \& I. A. Njodi. Reforms in higher education in Nigeria. Maiduguri: Awemark.

5. Adegbasan, S. O. (2011). Establishing quality assurance in Nigerian education system: Implication for educational managers. Edu. Res. Rev., 6(2),147-151.

6. Adeyemi, J. K. \& Uko-Aviomoh, E. E. (2003). Teaching manpower requirements for effective technical education delivery in Nigerian polytechnics. International Studies in Educational Administration, 31(3),132-142.

7. Adeyemi, I., \& Esere, M. (2013). ICT and higher educational system in Nigeria. Journal of Educational research and reviews, 8(2), 2021-2025.

8. Aduwa-Ogiegbaen, S. E. \& Iyamu, E. O. (2005). Using information and communication technology in secondary schools in Nigeria: Problems and prospects. Educational Technology \& Society,8,(1), 104-106.

9. Akpan, C. P. (2014). ICT competence and lecturers' job efficiency in Universities in Cros River State, Nigeria. International Journal of Humanities and Social Science, 4(10), 259-266.

10. Akuegwu, B. A. Ntukiden, P. J. Ntulgiden, E. P. \& Jaga, G. (2011) cited in Egomo, T. E., Eniyi, B. I. \& Tah, M. M. (2012). Availability and utilization of ICT tools for effective instructional delivery in tertiary institutions in Cross River State, Nigeria. Global Advanced Research Journal of Educational Research and Review. 1(8), 190-195. Retrieved from http:/garj.org/garjerr/index.htm.

11. Alabi, A. T., Issa, A. O., \& Oyekunle, R. A. (2012). The use of computer based testing method for the conduct of examinations at the University of Ilorin. Ife Journal of Educational Leadership, Administrative and planning (IJELAP),1(1), 225-227.

12. Ali, A. (2006). Conducting research in education and the social sciences. Enugu: Tashiwa Networks Ltd.

13. Andreas, C. (2012). Electronic commerce and the banking industry. the requirement and opportunities for new payment system using the Internet. British Journal of Educational Technology, 30(1), 25-41.

14. Archibong, I. A. (2006). An assessment of role performance effectiveness of academic heads in tertiary education institutions in Akwa Ibom and Cross River States. International Journal of Educational Management (IJEM),4(1), 12-13.

15. Asliogo, J. E. (2005).G.S.M Engineering Kit. Lagos: Ciemex Computer.

16. Astumbe, B. N.,Raymond, E., \& Enoch, E. B. (2012). Availability and utilization of e-leaning infrastructures in federal University of technology, Minna. Journal of Education and Practice, 3(13), 56-64.

17. Bavakutty, M. \& Salih Mohamed, T. K, (1999). Internet services in Calicut University. National Convention of Academic Libraries in the Internet era. Organised by INLIBNET, 18--20 Febuary, 1999. Ahembadad, Pp. 37-44.

18. Centre for Teaching and Learning (2014). Effective use of power point in lectures. The University of NEWCASTLE, Australia. www.newcastle.edu.au/ctl.

19. Dalhatu, A., Mamman, M. S., \& Abdullah, Y. (2020). Availability and utilization of ICT resources for increasing competency among lecturers in Bauchi State College of Education. ATBU Journal of Science, Technology and Education, 8(1), 188-196.

20. Fasae, S. E., \& Aladeniyi, F. R.(2010). Internet use by students of faculty of science in two Nigerian Universities library philosophy and practices. Retrieved from http://unllib.unl.ed/lpp. 
21. Federal Republic of Nigeria, (2014). National Policy on Education. Lagos.

22. Freeman, I. \& Hasnaoui, A. (2010). Information and communication technologies (ICT): A tool to implement and drive corporate social responsibility. Retrieved from https:// halshs.archieves.ouvertes.fr/hal-00495968/document.

23. Friedrich, S. (2008). Quality features of TC exam: An open source computer assessment software towards research agenda on computer assessment. Retrieved from: http:// www.nrent.org/about/CBT.home.asp.

24. Goh, E., \& Sigala, M. (2020). Integrating Information \& Communication Technologies (ICT) into classroom instruction: teaching tips for hospitality educators from a diffusion of innovation approach. Journal of Teaching in Travel \& Tourism, 20(2), 156-165.

25. Greene, L. (2013). History of ICT. Retrieved from http://history of ictgreene. blogsport.com/.

26. Gwang-Jo, K. (2009). ICT in education: Issues and questions. Global symposium on ICT in Education. Co-organised by the World Bank the Korean Ministry of Education, Science and Technology (MEST), South Korea. Retrieved from http://web. worldbank.org/WBSITE?

27. Gyaase, P. O., Gyamfi, S. A., Kuranchie, A., \& Koomson, F. S. (2020). The integration of information and communication technology in pre-university education in Ghana: A Principal Component Analysis. In Handbook of Research on Diverse Teaching Strategies for the Technology-Rich Classroom (pp. 109-123). IGI Global.

28. Habibi, A., Yusop, F. D., \& Razak, R. A. (2020). The role of TPACK in affecting preservice language teachers' ICT integration during teaching practices: Indonesian context. Education and Information Technologies, 25(3), 1929-1949.

29. Hepp, P. K., Hinostroza, T., Laval, C. \& Rehbein, O. A. (2011). Technology in schools: Education and technology. Technical Notes Series, 5(2), 1-86. A Publication World Bank.

30. Ifinedo, E., Rikala, J., \& Hämäläinen, T. (2020). Factors affecting Nigerian teacher educators' technology integration: Considering characteristics, knowledge constructs, ICT practices and beliefs. Computers \& Education, 146, 103760.

31. Igbineweka, V. O. (2013). Teaching and research functions in Nigerian Universities: How many lecturers use the internet ? Academic Research International, 4(4), 400-405.

32. Iheanacho, J. (2004). Fore word. In A. Mallum \& T. Abiola (eds.). Information services and appraisal techniques in guidance and counselling. Jos: Institute of Education Publications University Press.

33. Jibril, M. (2006). Information and communication technology in the service of education. A key note address on Annual Conference, Institute of Education, University of Nigeria, Nsuka. p.15-16.

34. Joseph, A. B., Fasa, R. A., Samuel, K. A.,\& Samuel, A. A. (2014). Internet use by academic staff of Rufus Giwa Polytechnic, Ondo State, Nigeria. American International Journal of Contemporary Research, 4(9), 99-103.

35. Kumar, R. \& Kaur, A. (2005). Internet and its use in the engineering colleges of Punjab, India: a case study. Webology 2 (44). Retrieved from http://webology. org/2005/v2ny21/html. 
36. Larsen, K., \& Lancrin, S. V. (2005). The impact of ICT on tertiary education: Advances and promises. OECD/ University of Michigan Conference. Washington DC.

37. Mitomo, H. (2020). Utilization of ICT in elementary and secondary education in Japan: Its policies and effects. In Telecommunications Policies of Japan (pp. 239-266). Springer, Singapore.

38. Mohammed, K. \& Yarinchi, B. M. (2013). Information communication technology (ICT) and media education: In historical perspective. European Scientific Journal, 9(20),198-200.

39. Ntui, A. I.,\& Inyang, C. L. (2015). Utilization of information and communication technology (ICT) resources and job effectiveness among library staff in University of technology, Nigeria. Journal of Education and Practice, 6(6), 102-105.

40. Nwankwo, J. I. (2014). Management in education: Modern approaches in education management. Ibadan: Giraffe Books.

41. Nwaokwa, E. \& Okoli, B. E. (2012). Information of communication technology on the influence performance of secretaries in government ministries in Nassarawa State North-Central Nigeria. Research Journal of Information Technology, 4(3), 93-97.

42. Ogunrewo, J. O \& Odusina, E. K. (2010). Appraisal of internet usage among academic staff members of Joseph Ayo Babalola University, Ikeji Arakeji, Osun State, Nigeria. Ozean Journal of Applied Sciences, 3(4), 279-385.

43. Ojo, O. J. (2014). Information and communication technology utilization, decision-making and administrative effectiveness of polytechnics in South West Nigeria. Unpublished Ph.D. Thesis, university of Ilorin, Nigeria.

44. Okojie, M. U. (2007). Information technology and effective teaching and learning: Focus of Educational Research and Development, 2(1), 1-14.

45. Olorundare, A. S. (2011). Utilisation of ICT in curriculum development, implementation and evaluation. In D. O. Durosaro \& A. A. Adegoke (eds). Higher education \& globalization. Lagos p. 11-22.

46. Onasanya, S. A., Shehu, R. A., Oduwaye, R. O., \& Shehu, L. A. (2010). Higher institutions lecturers' attitude towards integration of ICT into teaching and research in Nigeria. Research Journal of Information Technology, 2(1), 1-10.

47. Oniye, A. O., Yahaya, L. A \& Alawaye, A. S. (2011). The needs for integration of information communication technology(ICT) in Nigeria institutions of higher learning. In D. O. Durosaro \& A. A. Adegoke (Eds). Higher education \& globalization. Lagos: Stirling-Horden Publishers Ltd.

48. Onwumere, A. O. (2008). Information and communication technology: A new dawn in teaching and learning. A paper presented at Nigeria Association for Educational Media and Technology. Proceedings of the $29^{\text {th }}$ Annual Convention and International Conference.

49. Rana, K., Greenwood, J., \& Fox-Turnbull, W. (2020). Implementation of Nepal's education policy in ICT: Examining current practice through an ecological model. The Electronic Journal of Information Systems in Developing Countries, 86(2), e1211.

50. Safahieh, H. \& Asemi, A. (2008). Computer literacy skills of librarians: A case study of Isfahan University libraries, Iran. Retrieved from http:/dspace.fsktm.um.ed-my/ bitstream/1812/292/1/5HararIranLc.Pdf. 
51. Suárez-Rodríguez, J., Almerich, G., Orellana, N., \& Díaz-García, I. (2018). A basic model of integration of ICT by teachers: competence and use. Educational Technology Research and Development, 66(5), 1165-1187.

52. Sulaiman, A. Z. (2008). The needs for an integrated information and communication technology (ICT) for teachers and process. Proceedings of the $29^{\text {th }}$ Annual Convention and International Conference.

53. Suleman, O. K. (2009). Paper-Based and Electronic-Based record keeping: The transitional process. Kwara State Universal Basic Education Board Capacity Building Workshop Organized for principals' Exam Officers and Councillors in Junior Secondary Schools.

54. Tomel, K. M. (2005). Computer and the development of ICT. London: Routledge: Palmer.

55. Umoren, G. (2006). Information and communication technology and curriculum. Nigerian Journal of Curriculum Studies, 2(1), 57-83.

56. Victor, N. N., \& Faga, A. (2015). Utilisation of computer technology for academic work by lecturers of University of Jos- Nigeria. International Journal of Library and Information Science Studies, 1(2), 14-22.

57. Yusuf, H. T. (2005). Teacher education programme: Teacher educator's assessment of two university based curricula models. In D. O. Durosaro \& A. A. Adegoke (Eds). Higher Education \& globalization. Ibadan: Stirling-Horden Publishers ltd. 